\title{
JOURNAL OF THE SCIENCE OF FOOD AND AGRICULTURE
}

\section{A Journal of the Society of Chemical Industry}

Management Committee

M.P. Tombs (Chairman), University of Nottingham, UK.

D.S. Reid (North American Editor), University of California, Davis, USA.

P.J. van Soest (North American Editor). Cornell University, Ithaca, USA.

J. Blanshard, University of Nottingham, $U K$.

I.G. Burns, AFRC Institute of Horticultural Research, Wellesbourne, UK.

W.F.J. Cuthbertson, Harefield, UK.

E.R. Dinnis, Shaftesbury, UK.

R.J. Dowdell (Technical Editor), DAFS, Edinburgh, UK.

H. Fore (Technical Editor), Fore Consulting, Compstall, Stockport, UK.

C.H.S. Hitchcock, University of Surrey, Guildford, UK.

A.J. MacLeod, King's College, London, UK.

\section{AIMS AND SCOPE}

Journal of the Science of Food and Agriculture publishes original research and critical reviews in agriculture and food science, with particular emphasis on interdisciplinary studies at the agriculture/food interface. The journal covers fundamental and applied research and development of the production of crops and animals, comprising:

- Studies of plant and animal husbandry, physiology, yield and quality

- The interaction of agriculture with forestry and the environment

- Production and processing of human food, fibre, and animal feed

- Nutrition quality and sensory analysis, flavour, texture, safety and toxicity of important human foodstuffs, beverages and alcoholic drinks

The journal also carries reports of scientific meetings of the SCI Food Group, SCI Agriculture Group, and joint meetings with other societies.

\begin{abstract}
ED/INDEXED IN:
Current Contents, BIOSIS (Biological Abstracts), Biological and Agricultural Index, Chemical Abstracts, Science Citation Index, C.A.B. Abstracts, Index Medicus, AGRICOLA database, Excerpta Medica/Embase.
\end{abstract}

\section{SUBSCRIPTION INFORMATION}

ISSN: 00225142

Frequency: 4 issues per volume, 4 volumes per year.

Volumes 50-53 (1990): UK delivery $£ 225.00$; Outside UK delivery $£ 247.00$

All subscriptions are airspeeded.

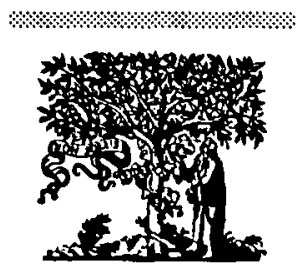

Orders and requests for sample copies should be sent to:

ELSEVIER SCIENCE PUBLISHERS LTD.

Crown House, Linton Road, Barking, Essex IG11 8JU, UK.

or for customers in North America

Elsevier Science Publishers, Journal Information Center, 655 Avenue of the Americas, New York, NY 10010, USA. 


\section{JOURNAL OF FOOD ENGINEERING}

\section{EDITORS}

\section{B. McKenna, Department of Agricultural and Food Engineering,}

University College Dublin, Ireland.

M.R. Okos, Department of Biochemical and Food Process Engineering,

Purdue University, West Lafayette, Indiana 47907, USA.

\section{AIMS AND SCOPE}

The journal publishes papers on any subject at the interface between food and engineering, particularly those of relevance to industry, including:

- Engineering properties of foods

- Processing measurement, control, packaging, storage and distribution

- Engineering aspects of the design and production of novel foods and of food service and catering

- Design and operation of food processes, plant and equipment

- Economics of food engineering, including the economics of altemative processes

Accounts of food engineering achievements are of particular value.

\section{ABSTRACTED/INDEXED IN:}

Engineering Index, Chemical Abstracts, BIOSIS (Biological Abstracts), AGRICOLA database, Engineering Abstracts, IFIS.

\section{SUBSCRIPTION INFORMATION}

\section{ISSN: 02608774}

Frequency: 4 issues per volume.

Volumes 11 and 12 (1990): UK delivery $£ 156.00$; Outside UK delivery $£ 172.00$

All subscriptions are airspeeded.

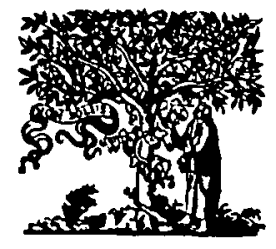

Orders and requests for sample copies should be sent to:

ELSEVIER SCIENCE PUBLISHERS LTD.

Crown House, Linton Road, Barking, Essex IG11 8JU, UK.

or for customers in North America

Elsevier Science Publishers, Journal Information Center, 655 Avenue of the Americas, New York, NY 10010, USA. 


\title{
JOURNAL OF DAIRY RESEARCH
}

\author{
EDITED BY \\ W. MANSON \\ Hannah Research Institute, Ayr KA6 5HL, UK \\ B. A. ROLLS \\ AFRC Institute of Food Research, Reading Laboratory, \\ Shinfield, Reading RG2 9AT, UK
}

\author{
Assistant Editors \\ B. F. BONE \\ MARY C. A. GRIFFIN \\ C. J. WILDE
}

Editorial Assistant

B. GILLIAN DAY

Secretary

L. C. FITZGERALD

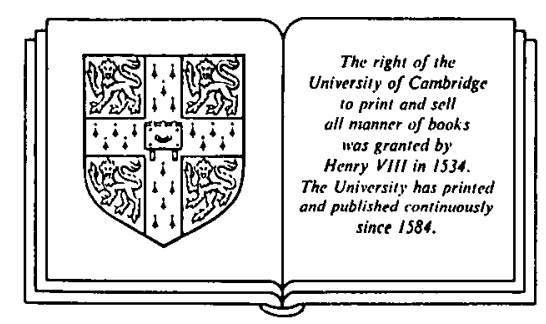

VOLUME 57, 1990

CAMBRIDGE UNIVERSITY PRESS 


\section{PUBLISHED BY \\ THE SYNDICS OF THE CAMBRIDGE UNIVERSITY PRESS}

The Pitt Building, Trumpington Street, Cambridge CB2 1RP

40 West 20th Street, New York, NY 10011

10 Stamford Road, Oakleigh, Melbourne 3166 Australia

(C) Proprietors of Journal of Dairy Research 1990 


\section{Contents}

No. 1 (February 1990)

The onset of mammary secretion of medium-chain-length triglyceride fatty acids in the cow milk pre-partum. G. Thompson and A. FAulkner

Ability of bovine mammary macrophages to enhance proliferation of autologous blood and mammary secretion lymphocytes. C. CoNCHA and O. Holmberg.

Compensatory milk production within the bovine udder : effects of short-term non-milking of single quarters. J. HAMANN and J. REICHMUTH

Fatty acid composition and milk quality related to feeding Ca-saponified palm acid oil to different breeds of dairy cows. J. E. Hermansen and P. Lund

Effect of cleaning-in-place disinfectants on wild bacterial strains isolated from a milking line. T. Mattila, M. Manninen and A.-L. Kyläsiurola .

Composition of Alpine goats' milk during lactation in Greece. L. Voutsinas, C. Pappas and M. Katsiari

Milk protein polymorphism in Danish dairy cattle and the influence of genetic variants on milk yield. A.-M. BeCH and K. R. Kristiansen . . .

Ion-exchange fast protein liquid chromatography: optimization of the purification of caseins using a non-denaturing detergent. M. ST-MARTIN and P. PAQUIN

Repression of Pseudomonas fluorescens extracellular lipase secretion by arginine. L. Fernández, C. San José and R. C. McKellar .

Proline specific peptidases of Streptococcus cremoris AMS. M. Воотн, W. J. Donnelly, I. Ni Fhaoláin, P. V. Jennings and G. O'Cuinn

Purification and characterisation of a post proline dipeptidyl aminopeptidase from Streptococcus cremoris AM2. M. BоотH, I. Ni.FhaolárN, V. JenNINGS and G. O'CuINN

A study of surface hydrophobicity of milk proteins during enzymic coagulation and curd hardening. C. Peri, A. Pagliarini, S. Iametti and F. Bonomi

Effects of chromatographically pure bovine chymosin and pepsin A on cheese curd firmness. A. Andrén and C. Von ReEdTz

Influence of chromatographically pure bovine chymosin and pepsin $A$ on cheese curd synthesis. H. Andersson and A. Andrén .

Characterization of wild strains of Lactococcus lactis subsp. lactis isolated from Cabrales cheese. B. Mayo, C. Hardisson and A. F. Braña 


\section{Short communications}

A scheme for the partial fractionation of cheese peptides. M. O'Sullivan and P. F. Fox

Repeatability of milk clotting aptitude evaluated by lactodynamographic analysis. A. Caroli, P. Bolla, G. Pagnacco, M. Rampillo and L. Degano

Measurement of proteolysis in milk and cheese using trinitrobenzene sulphonic acid and a new dissolving agent. G. Humbert, M.-F. Guingamp, R. Kouomegne and G. LINDEN

Titration - a rapid method for the determination of proteolysis in cheese. P. OllikaINEN

No. 2 (May 1990)

Rationale of feeding systems for lactating dairy cows. C. L. JoHnson and C. L. Tran

Teat length and penetration into teatcup during milking in Norwegian Red Cattle. O. Renningen and A. D. Reitan

Influence of static and dynamic teat characteristics and milking time on udder health in Norwegian Red Cattle. O. Rønningen and A. D. ReItan

Effect of dietary unsaturated fatty acids in various forms on the de novo synthesis of fatty acids in the bovine mammary gland. W. BANks, J. L. Clapperton and A. K. Girdler

Changes in the physical properties of ultra high temperature processed buffalo milk during storage. D. K. Sharma and D. N. Prasad

Detection of cows' milk in ewes' milk and cheese by an indirect enzyme-linked immunosorbent assay (ELISA). E. Rodríguez, R. Martín, T. García, P. E. HernándeZ and B. SANZ .

An improved method for determining the nitrogen solubility of caseinates. W. KNEIFEL and A. BeUREL

Effects of added salts on the heat stability of recombined concentrated milk. M.-A. Augustin and P. T. Clarke .

Ultraviolet spectroscopic studies and the prediction of the feathering of cream in filter coffees. L. Hamboyan and D. Pink

A survey of the microflora of raw and pasteurized milk and the sources of contamination in a milk processing plant in Addis Ababa, Ethiopia. T. MahaRI and B. A. Gashe

Comparison of rapid tests for assessing UHT milk sterility. J. A. Reinheimer and M. R. Denkow

Prolidase activity of Lactococcus lactis subsp. cremoris AM2: partial purification and characterization. M. Bоoth, V. Jennings, I. NíFhaOLain and G. O'CuInN 
Prevention of gastrointestinal infection using immunobiological methods with milk fermented with Lactobacillus casei and Lactobacillus acidophilus. G. Perdigon, M. E. Nade de Macias, S. Alvarez, G. Oliver and A. A. P. DE R. Holgado

Firmness values of three-phase, milk fat-based table spreads as determined by composition and temperature. J. Foley, M. A. Moran and C. M. Cooney

Ripening changes in Kopanisti cheese. S. E. Kaminarides, E. M. Anifantakis and E. Alichanidis

\section{Short communication}

Preparation and consumer acceptability tests of fermented camel milk in Kenya. Z. Farah, T. StreifF and M. R. Bachmann

\section{No. 3 (August 1990)}

Milk yield and mammary function in dairy cows milked four times daily. J. E. Hillerton, C. H. Knight, A. Turvey, S. D. Wheatley and C. J. WILDE . . . . . . . . . . . . .

Effect on cow performance and milk fat composition of including full fat soyabeans and rapeseeds in the concentrate mixture for lactating dairy cows. J. J. Murphy, G. P. McNeill, J. F. Connolly and P. A. Gleeson

The effect of udder preparation before milking and contamination from the milking plant on bacterial numbers in bulk milk of eight dairy herds. C. H. McKinnon, G. J. Rowlands and A. J. Bramley

A method for assessing loss in milk yield due to subclinical mastitis. M. Oshima, T. Yoshida, K. Koyama and T. Moriyama

The diagnosis of subclinical mastitis by redefinition of the interquarter ratio and definition of the interquarter ratio using analysis of variance methods. K. KNUDSEN and N. E. Jensen . . . . . .

Changes in the concentration of glucose and galactose in the peripheral blood of sucking piglets. M. A. Holmes, P. G. Arthur and P. E. Hartmann .

A model heat exchange apparatus for the investigation of fouling of stainless steel surfaces by milk II. Depth of fouling material at $140^{\circ} \mathrm{C}$, its adhesion and depth profiling. C. L. Foster and M. L. Green . . . .

Cleavage of the linkage between colloidal calcium phosphate and casein on heating milk at high temperature. T. AokI, T. UMEDA and Y. Kako .

$\mathrm{A}^{43} \mathrm{Ca}$ and ${ }^{31} \mathrm{P}$ NMR study of the calcium and phosphate equilibria in heated milk solutions. N. M. Wahlgren, P. Dejmek and T. Drakenberg

Acid coagulation of casein miscelles: mechanisms inferred from spectrophotometric studies. N. A. Bringe and J. E. Kinsella . . . .

Comparative emulsifying properties of sodium caseinate and whey protein isolate in $18 \%$ oil in aqueous solutions. J. Foley and C. O'Connelu . 
Relationship between amplitude and phase measurements of photoacoustic signal in the infrared region and water concentration in condensed milk. R. Martel, P. Paquin and L. Bertrand

Effect of threonine and glycine on acetaldehyde formation in goats' milk yogurt. G. Rysstad, W. J. Knutsen and R. K. Abrahamsen

Observations on plasmin activity in cheese. N. Y. FARKYE and P. F. Fox .

\section{Short communication}

Comparison of oestrone sulphate concentrations in mammary secretions during lactogenesis and lactation in dairy ruminants. M. Hamon, I. R. Fleet and R. B. Heap

No. 4 (November 1990)

Variation with season and lactation of plasmin and plasminogen concentrations in Montbeliard cows' milk. S. Benslimane, M. J. DogninBergeret, J.-L. Berdague and Y. Gaudemer

Associations between the bovine major histocompatibility complex (BoLA) and milk production in Icelandic dairy cattle. S. P. Simpson, $O$. Oddgeirsson, J. V. Jonmundsson and R. A. Oliver

Milk yield and mammary function in goats during and after once-daily milking. C. J. WILDE and C. H. KNIGHT .

Yield and composition of milk from lactating mares : effect of lactation stage and individual differences. M. Doreau, S. Boulot, J.-P. Barlet and P. Patureau-Mirand .

The effects of intraruminal infusions of urea on the voluntary intake and milk production of cows receiving grass silage diets. J.-J. Choung, D. G. Chamberlain, P. C. Thomas and I. Bradbury

Effect of plane of nutrition on insulin sensitivity during lactation in the ewe. J. A. Metcalf and T. E. C. Weekes . . . . . . .

Effects of dehydration and arginine vasopressin infusions on the production of milk and the morphology of the goat udder. K. DAHLBORN, J. H. Hilali and H. Rodriguez-Martinez.

Local control of the onset of mammary extraction of plasma triglycerides during lactogenesis in the goat. G. E. Thompson

Measurement of machine-induced changes in thickness of the bovine teat. J. Hamann and G. A. Mein

Glycoproteins in the heat- and acid-stable fraction of ovine milk. E. Alichanidis and A.-M. Michaelidou . . . . . . .

HPLC and GLC analysis of the triglyceride composition of bovine, ovine and caprine milk fat. L. J. R. Barron, M. T. G. Hierro and G. Santa-María 
Effect of coagulation and washing conditions on fines, water-holding capacity and microstructure of acid casein curd. J. Fichtali, F. R. VAN DE VOORT and C. J. Toupin . . . . . . . . . . . .

Enhancement of proteolysis in bovine skim milk by heat and chemical treatments. Y. IGARASHI. . . . . . . . . .

The cheesemaking potential of milk concentrated up to four-fold by ultrafiltration and heated in the range $90-97^{\circ} \mathrm{C}$. M. L. Green . .

Cheddar cheesemaking from whole milk concentrated by ultrafiltration and heated to $90^{\circ} \mathrm{C}$. M. L. Green . . . . . . . . .

Accelerated ripening of Cheddar cheese with the aminopeptidase of Brevibacterium linens and a commercial neutral proteinase. K. HAYASHI, D. F. Revell and B. A. LAw

Interactive effect of $\mathrm{H}_{2} \mathrm{~S}$ production from cysteine and methanethiol production from methionine in milk fat-coated microcapsules containing Brevibacterium linens. S. C. KIM, M. KIM and N. F. OLson

New equation for prediction of water activity in unripe cheese. P. López, A. Marcos and M. A. Esteban . . . . . . .

Proteinase, peptidase and esterase activities of cell-free extracts from wild strains of Lactobacillus delbrueckii subsp. bulgaricus and Streptococcus salivarius subsp. thermophilis isolated from traditional Greek yogurt. G. Kalantzopoulos, E. Tsakalidou and E. Manolopoulou 


\section{DIRECTIONS TO CONTRIBUTORS}

\section{GENERAL}

Two copies of manuscripts should be sent to the Editor, Journal of Dairy Research, Dr B. A. Rolls, AFRC Institute of Food Research, Reading Laboratory, Shinfield, Reading RG2 9AT, UK. Submission of a paper will be held to imply that it reports unpublished original work, that it is not under consideration for publication elsewhere, and that if accepted for the Journal it will not be published elsewhere in any language, without the consent of the Editors.

\section{FORM OF PAPERS}

The author should follow these directions carefully, and consult a current issue of-the Journal for guidance on details of typographical and other conventions.

Every paper should be headed with its title, the names and initials of the authors (each author supplying one given name) and the name and address of the laboratory where the work was done.

Papers should be in English, using the spelling of the Shorter Oxford English Dictionary. They should be typed with double spacing, on one side only of the sheets, and with ample margins for editorial annotations.

Papers should in general be divided into the following parts in the order indicated: (a) Summary, brief and selfcontained; (b) Introductory paragraphs, briefly explaining the object of the work but without giving an extensive account of the literature; (c) Experimental or Materials and Methods; (d) Results; (e) Discussion and Conclusions; $(f)$ Acknowledgements without a heading; $(g)$ References. With some types of material headings other than $(c),(d)$ and $(e)$ may be preferable.

The use of footnotes should be avoided if possible Underlining should be used only to indicate italics. Proper nouns, including trade names, should be given a capital initial letter. Manufacturers or suppliers of materials and equipment, with their addresses, should be given. The typescript should carry the name and address of the person to whom the proofs are to be sent, and give a shortened version of the paper's title, not exceeding 45 letters and spaces, suitable for a running title in the Journal.

\section{TABLES}

Tables should be numbered and should carry headings describing their content. They should be comprehensible without reference to the text. They should be typed on separate sheets and their approximate positions in the text indicated. To minimize the cost of printing, the number and size of tables should be kept to an absolute minimum.

\section{ILLUSTRATIONS}

Line drawings and photographs, which must be originals, should be numbered as Figures in Arabic numerals. Drawings should be in Indian ink, on Bristol board or cartridge paper. However, a technique which may be more convenient to authors is to use a double-sized folded piece of tracing paper, or translucent graph paper, with the drawing on one half and the other half acting as a flyleaf. There should be no lettering or numerals on the drawing itself.

Attached to every figure there should be a translucent flyleaf cover on the outside of which should be written legibly: (a) title of paper and name of author; $(b)$ figure; $(c)$ the figures and lettering, which are intended to appear on the finished block, in the correct positions relative to the drawing underneath. Each paper should have a separate typed sheet listing figure numbers with their legends, and the approximate positions of illustrations should be indicated in the text.

The photographs and diagrams should be about twice the size of the finished block and not larger overall than the sheets on which the paper itself is typed. For a figure measuring $250 \mathrm{~mm} \times 150 \mathrm{~mm}$ all lines, axes and curves should be $0.4 \mathrm{~mm}$ thick, thus ___ Graph symbols in order of preference are $O \quad \Delta \Delta, \square \square, \times+$, and for a $250 \mathrm{~mm} \times 150 \mathrm{~mm}$ graph the circles should be $3 \mathrm{~mm}$ in diam. The triangles should be equilateral of $3 \mathrm{~mm}$ side, and the squares also of $3 \mathrm{~mm}$ side. The crosses should have lines $3 \mathrm{~mm}$ long at right angles. Scale marks on the axes should be on the inner side of each axis and should be $3 \mathrm{~mm}$ long.

\section{SHORT COMMUNICATIONS}

Short communications or notes of not more than 2500 words or the equivalent space in print and without a summary will also be published.

\section{REFERENCES}

In the text, references should be quoted by whichever of the following ways is appropriate: Arnold \& Barnard (1900); Arnold \& Barnard (1900a); Arnold \& Barnard $(1900 a, b)$; Arnold et al. (1900). Give both names for two authors. For three or more authors give the first name et $a l$. on all occasions, adding $a, b$, etc. to the date if there is any ambiguity.

References should be listed alphabetically at the end of the paper. Titles of journals should be given in full, authors' names should be in caps and their initials included. Each reference should be punctuated and set out thus: ARNOLD, T. B., BARNARD, R. N. \& COMPOUND, P. J. 1900. Title of paper. Journal of Dairy Research 18, 158-165, and references to books should include names of authors, year of publication, title, names of editors, town of publication and name of publisher in that order, thus: ARNOLD, T. B. 1900 In Dairying, vol. 1, pp. 5-11 (Ed. R. W. Brown). London: Brown and Chester.

It is the duty of the author to check all references.

\section{UNITS, SYMBOLS AND ABBREVIATIONS}

SI units must be used, as explained in British Standards Institution publication BS 5555: 1981 (Specification for SI units and recommendations for the use of their multiples and of certain other units). Until SI units are widely understood, it is permissible to give the equivalent value in other units in parenthesis. Symbols and abbreviations used are those of British Standard 5775 (Specification for Quantities, Units and Symbols).

\section{DESCRIPTIONS OF SOLUTIONS}

Normality and molarity should be indicated thus: $\mathrm{N}-\mathrm{HCl}$, $0 \cdot 1 \mathrm{~m}-\mathrm{NaH}_{2} \mathrm{PO}_{4}$. The term ' $\%$ ' means $\mathrm{g} / 100 \mathrm{~g}$ solution. For $\mathrm{ml} / 100 \mathrm{ml}$ solution the term ' $\%(\mathrm{v} / \mathrm{v})$ ' should be used and for $\mathrm{g} / 100 \mathrm{ml}$ solution the correct abbreviation is ' $\%$ $(w / v)^{\prime}$.

\section{OFFPRINTS}

Order forms giving quotations for offprints are sent to authors with their proofs. 


\section{Continued from back cover}

Interactive effect of $\mathrm{H}_{2} \mathrm{~S}$ production from cysteine and methanethiol production from methionine in milk-fat-coated microcapsules containing Brevibacterium linens

S. C. KIM, M. KIM and N. F. OLSON

New equation for prediction of water activity in unripe cheese

P. LÓPEZ, A. MARCOS and M. A. ESTEBAN

Proteinase, peptidase and esterase activities of cell-free extracts from wild strains of Lactobacillus delbrueckii subsp. bulgaricus and Streptococcus salivarius subsp.

thermophilis isolated from traditional Greek yogurt

G. KALANTZOPOULOS, E. TSAKALIDOU and E. MANOLOPOULOU 


\section{JOURNAL OF DAIRY RESEARCH}

Volume 57 Number 4 November $199^{\circ}$

CONTENTS

Original articles

Variation with season and lactation of plasmin and plasminogen concentrations in

Montbeliard cows' milk

S. BENSLIMANE, M. J. DOGNIN-BERGERET, J.-L. BERDAGUE and Y. GAUDEMER

423-435

Associations between the bovine major histocompatibility complex (BoLA) and milk production in Icelandic dairy cattle

S. P. SIMPSON, O. ODDGEIRSSON, J. V. JONMUNDSSON and R. A. OLIVER

$437-440$

Milk yield and mammary function in goats during and after once-daily milking

C. J. WILDE and C. H. KNIGHT

$441-447$

Yield and composition of milk from lactating mares: effect of lactation stage and individual differences

M. DOREAU, S. BOULOT, J.-P. BARLET and P. PATUREAU-MIRAND

The effects of intraruminal infusions of urea on the voluntary intake and milk

production of cows receiving grass silage diets

J.-J. CHOUNG, D. G. CHAMBERLAIN, P. C. THOMAS and I. BRADBURY

$455-464$

Effect of plane of nutrition on insulin sensitivity during lactation in the ewe

J. A. METCALF and T. E. C. WEEKES

$465-478$

Effects of dehydration and arginine vasopressin infusions on the production of milk and

the morphology of the goat udder

K. DAHLBORN, J. H. HILALI and H. RODRIGUEZ-MARTINEZ

Local control of the onset of mammary extraction of plasma triglycerides during

lactogenesis in the goat

G. E. THOMPSON

Measurement of machine-induced changes in thickness of the bovine teat

J. HAMANN and G. A. MEIN

Glycoproteins in the heat- and acid-stable fraction of ovine milk

E. ALICHANIDIS and A.-M. MICHAELIDOU

HPLC and GLC analysis of the triglyceride composition of bovine, ovine and caprine milk fat

L. J. R. BARRON, M. T. G. HIERRO and G. SANTA-MARÍA

Effect of coagulation and washing conditions on fines, water-holding capacity and microstructure of acid casein curd

J. FICHTALI, F. R. VAN DE VOORT and C. J. TOUPIN

Enhancement of proteolysis in bovine skim milk by heat and chemical treatments

Y. IGARASHI

$541-548$

The cheesemaking potential of milk concentrated up to four-fold by ultrafiltration and heated in the range $90-97^{\circ} \mathrm{C}$

M. L. GREEN

Cheddar cheesemaking from whole milk concentrated by ultrafiltration and heated to $90{ }^{\circ} \mathrm{C}$

M. L. GREEN

Accelerated ripening of Cheddar cheese with the aminopeptidase of Brevibacterium

linens and a commercial neutral proteinase

K. HAYASHI, D. F. REVELL and B. A. LAW

$571-577$

Continued inside back cover

(C) Proprietors of Journal of Dairy Research 1990

Printed in Great Britain by the University Press, Cambridge 